\title{
健常者の車いす片側下肢駆動の分析
}

\section{Motion Analysis of Wheelchair Propulsion with the Lower Legs of Normal Persons}

川田 教平 ${ }^{1)}$ 山本 澄子2)

KYOHEI KAWADA ${ }^{1)}$, SUMIKo YAMAMOTO ${ }^{2)}$

1) Ryotokuji University Department of Physical Therapy Faculty of Health Sciences: 5-8-1 Akemi, Urayasu-city, Chiba 279-8567, Japan. TEL +81 47-382-2111 FAX +8147-382-2017 E-mail kawada@ryotokuji-u.ac.jp

2) International University of Health and Welfare, Graduate School

Rigakuryoho Kagaku 24(3): 311-315, 2009. Submitted Oct. 3, 2008. Accepted Dec. 24, 2008.

ABSTRACT: [Purpose] The purpose of this study was to get basic data of wheelchair propulsion movements with one leg of normal persons. [Subjects] Three normal persons participated in this study. [Methods] The wheelchair propulsion movements with one leg were recorded by a 3D motion analysis system, VICON. [Results] It was shown that the pelvis and the trunk moved to the opposite direction in the horizontal and frontal planes. The drive speed, stride and cadence rose as the trunk inclined backwards in propulsion. [Conclusion] The resulys suggest that normal persons could maintain a symmetric posture in one-legged wheelchair propulsion.

Key words: normal persons, wheelchair driving, motion analysis

要旨：〔目的〕本研究の目的は, 健常者の駆動中の身体運動を分析して, 車いす片側下肢駆動の基礎データを得る ことである。【対象〕対象は健常者 3 名とした。〔方法〕自由駆動と背もたれ駆動の 2 条件の車いす片側下肢駆動動 作を 3 次元動作解析装置VICON MXより計測した。〔結果〕2 条件の駆動様式ともに骨盤と上部体幹は, 水平面と前 額面上で逆方向へ動く傾向を示した。背もたれ駆動において, 駆動速度とストライド, ケイデンスは上昇する傾向 を示した。〔結語〕健常者では体幹伸展位での車い寸片側下肢駆動でも姿勢を左右対称に保つ能力があることが推 察された。

キーワード：健常者, 車いす下肢駆動, 動作分析

1) 了徳寺大学 健康科学部理学療法学科：千葉県浦安市明海5-8-1（†279-8567） TEL 047-382-2111 FAX 047-382-2017

2) 国際医療福祉大学大学院

$$
\text { 受付日 2008年10月3日＼cjkstart受理日２008年12月24日 }
$$




\section{I.はじめに}

脳卒中片麻痺者（以下，片麻痖者）の車い寸駆動は, 比較的早期に獲得可能な動作である。例えば歩行困難 な者や歩行獲得前の訓練途上の者が車い寸を使用する。 駆動様式は様々であるが, 特殊な身体症状を呈する場 合を除いて, 非麻痺側上下肢を使用した駆動動作を行っ ている。なかでも下肢の役割は舵取りと駆動といわれ ており, 直進や方向転換ともに重要な位置を占めてい る。臨床において, セラピストは駆動側下肢の機能強 化を目的に車いす駆動方法の指導を行うことが多い。 駆動動作に限らず, 非麻㾝側の機能を強化することは 日常生活動作（以下, ADL 動作）の自立度を高めるた めに必要であると思われる。

一方，片麻痺者の車い寸駆動は，非麻痺側を使用す るため, 駆動するということ自体が非対称な姿勢を助 長しうるという問題をもつ。そのため，車いすの調整 の重要性が指摘されている ${ }^{1,2)}$ が, 病院や施設に配置さ れている車いすの多くは標準型車いすであり, 個々の 片麻痺者に合わせて調整することが困難であることが 多い。また, 麻疩や筋緊張克進, 身体認知といった片 麻瘏者の身体機能や認知機能の低下の問題から駆動す る度に非対称な姿勢を増強させている片麻痺者が多く みられる。片麻痺者の車い寸上の姿勢の重要性が指摘 されているが，実際の駆動中の身体運動に関する研究 は少ない。健常者を対象とした研究では, 体幹は駆動 相に前屈すると報告している3)。また, 片麻痺者を対象 とした研究では, 健常な人で認められた体幹の前屈は 認められなかったと報告している4)。健常者と片麻痺 者の駆動中の矢状面上の体幹の動きについては報告さ れているが，駆動中の前額面，水平面上の動きを計測 した報告はない。また，車いす駆動中には身体がバッ クサポートとシートに接触しているため, 影響を受け 易い骨盤の動きも知る必要があると思われる。健常者 を対象としたのは, 片麻疩者の分析を行うにあたり, 健常者の動きを知ることで, 姿勢のくずれにつながる 片麻痺者の駆動動作の問題点を明確にするためである。

そこで本研究では, 健常者の駆動中の身体運動を分 析して, 車い寸片側下肢駆動の基礎デー夕を得ること を目的とした。

\section{II. 対象と方法}

1. 対象

対象は整形外科疾患がない健常者 3 名とした。健常
者3名の性別は男性 1 名, 女性 2 名で, 平均年齢は $28 \pm$ 2.64 歳であった。研究計画に関しては国際医療福祉大 学研究倫理小委員会にて承認を得て, 計測実施前に各 被験者に対して研究計画の説明と同意書を示し, 研究 の内容とリスクに関する説明を文書と口頭で行い同意 を得たのち計測を行った。

\section{2. 方法}

計測課題は，片側下肢駆動による直進走行とし，自 由駆動と背もたれ駆動の 2 条件で実施した。自由駆動 とは, 計測者が『正面を向いて右足で駆動して下さい』 と指示した時の駆動と定義し, 背もたれ駆動とは, 計 測者が『正面を向いて背もたれにもたれ，右足で駆動 して下さい』と指示した時の駆動と定義した。2 条件の 設定については, 先行研究から体幹の運動方向が異な ることから設定した。計測には3次元動作解析装置VICON

MX (VICON PEAK社製, カメラ8台), 日進医療機 器製採型用車いす（以下，採型用車いす）を使用した。 駆動路は, 大型床反力計 4 枚 (共和電業製, $1.8 \times 0.6 \mathrm{~m}$ ) 上とし, 床反力計の端からそれぞれ $1 \mathrm{~m}$ の補助駆動路 を設定し, 計 $5.6 \mathrm{~m}$ の駆動路とした。計測した位置デー タは, サンプリング周波数 $120 \mathrm{~Hz}$ でPCに取り込んだ。

採型用車い寸は, 駆動輪を 24 インチ, キャスターを 5 インチとした。シートの前後差は $2 \mathrm{~cm}$ に固定した。ま た，バックサポートは下部をあけて，骨盤に貼付した マーカーが後方から見えるようにした。採型用車い寸 の調整箇所は, シート高, シート奥行き, シート幅, アー ムレスト高, バックサポート高の5 項目とした。身体寸 法の測定から採型用車い寸の調整 5) は身体寸法をメ ジャーを使用して計測した。

身体マーカー位置は, 両肩峰, Th2, 両上前腸骨棘 (以下 ASIS), 両股関節点, 両上後腸骨棘（以下 PSIS）, 両膝関節点，両足関節点，両第4 中足骨骨頭とし，15点 のマーカーを貼付した。上部体幹と骨盤の角度を算出 するために, 上部体幹座標系は両側の肩峰と Th2 のマー カーを用いて設定し, 骨盤座標系は, 両側のASIS と PSIS のマーカーを用いて設定した。

非駆動側上肢の位置は任意とし，採型用車い寸に乗 車後, 全被験者に対してフットサポート高を設定し, 静止座位の計測を行った。その後, 駆動開始地点まで の移動については, 研究補助者が行った。駆動動作の 計測中, 足部の接地状況を観察するためにデジタルビ デオカメラで側方より撮影した。デジタルビデオカメ ラの位置は, 全被験者で同位置とした。この設定で3 駆 動周期の計測ができ, そのうち 15 点のマーカーの全て 
を認識できた中央の 1 駆動周期のデータを使用した。

評価パラメーターは, (1)駆動速度 (2)ストライド (3)ケイデンス (4)駆動中の骨盤傾斜と回旋角度, 上部 体幹側屈と回旋角度と変化量 (5)静止座位時から股関 節屈曲時期までの骨盤後傾角度の変化量（以下，ズレ 角度）とした。

デジタルビデオカメラとVICONで計測した位置デー タの中で, 足関節点のマーカー位置から足部が床に接 地した時期（以下，足部接地）を，第 4 中足骨骨頭の マーカー位置から足部が床から離れた時期を検出し, 駆動速度とストライド, ケイデンスを算出した。骨盤 と上部体幹角度は, 3 次元動作解析装置から得られた位 置データから Body Builder ver.3.6を用いてX軸, Y 軸, Z 軸周りの角度を算出した。上部体幹座標系の $\mathrm{Y}$ 軸周り の角度を『側屈角度』, $\mathrm{Z}$ 軸周りの角度を『回旋角度』, $X$ 軸周りの角度を『前後屈角度』と定義した。また, 骨 盤座標系の $\mathrm{Y}$ 軸周りの角度を『傾斜角度』, $\mathrm{Z}$ 軸周りの 角度を『回旋角度』, $\mathrm{X}$ 軸周りの角度を『前後傾角度』 と定義した。X軸では『後屈』と『後傾』はマイナス, 『前屈』と『前傾』はプラスと符号化した。 $\mathrm{Y}$ 軸と $\mathrm{Z}$ 軸 に関しては，非駆動側方向への『回旋』『側屈』『傾斜』 をマイナス, 駆動側方向への『回旋』『側屈』『傾斜』を プラスと符号化した。算出した角度は，1駆動周期を $100 \%$ として時間軸を正規化した。駆動側の股関節角度 は, 臨床歩行分析研究会ソフトウェアDIFF Gait, Wave eyes を用いて角度算出を行った。本論文では, 足部が 床に接地している時期を『駆動期』, 足部が床から離れ ている時期を『惰走期』と定義した。骨盤後傾角度の ズレ角度をみるために, 駆動期における駆動側股関節 角度変化から股関節屈曲ピーク時（以下，屈曲ピーク 時）と股関節伸展ピーク時（以下，伸展ピーク時）の 骨盤後傾角度に注目して分析を行った（図1）。

\section{III. 結 果}

表 1 に駆動様式別の駆動速度とストライド，ケイデ ンスの比較を示した。算出された值の平均值と標準偏 差を表中に示した。背もたれ駆動において, 駆動速度 とストライド，ケイデンスの上昇が認められた。

図 2 に 1 駆動周期中における駆動様式別の骨盤傾斜, 上部体幹側屈角度例を, 図 3 に 1 駆動周期中における駆 動様式別の骨盤回旋，上部体幹回旋角度を例示した。2 条件の駆動様式ともに骨盤と上部体幹は, 水平面と前 額面上で逆方向へ動く傾向を示した。他の 2 名につい ても同様な傾向を示した。

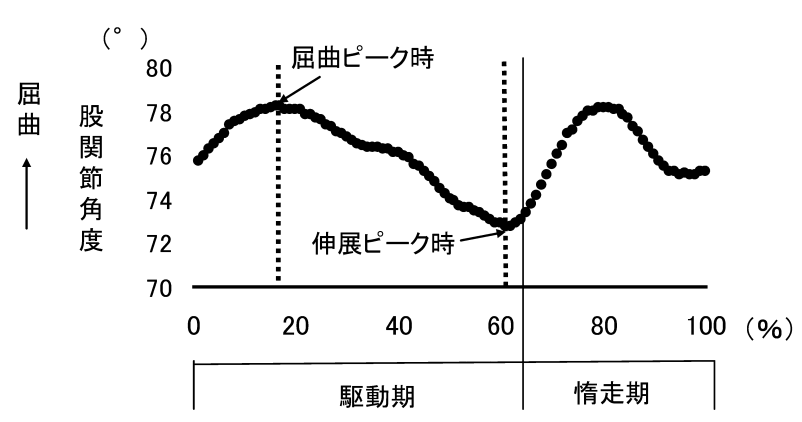

図1 1駆動周期における駆動側の股関節角度変化例

表1 駆動様式別での駆動速度, ストライド, ケイデンスの 比較

\begin{tabular}{lrr}
\hline & \multicolumn{1}{c}{ 自由駆動 } & 背もたれ駆動 \\
\hline 駆動速度 $(\mathrm{m} / \mathrm{sec})$ & $0.45 \pm 0.07$ & $0.79 \pm 0.13$ \\
ストライド $(\mathrm{m})$ & $0.80 \pm 0.18$ & $0.87 \pm 0.08$ \\
ケイデンス $(\mathrm{steps} / \mathrm{min})$ & $31.55 \pm 0.29$ & $58.55 \pm 0.90$ \\
\hline
\end{tabular}

駆動様式別の值は被験者 3 名の平均值と標準偏差を示す.

表 2 に駆動期における駆動様式別の骨盤と上部体幹 角度の変化量を示した。骨盤と上部体幹角度の変化量 は, 駆動期のそれぞれの角度の最大值と最小值の差を 算出し, 3 名の平均值と標準偏差を表中に示した。駆動 様式により, 大きな変化は見られなかった。

表 3 に静止座位から屈曲ピーク時までの骨盤後傾の ズレ角度を示した。被験者である健常者 3 名の駆動様 式で算出された值の平均值を表中に示した。背もたれ 駆動において, 駆動期の股関節屈曲ピークまでに骨盤 後傾のズレ角度が大きくなる傾向を示した。

\section{IV. 考 察}

健常者の自由駆動と背もたれ駆動の分析の結果, 2 条 件の駆動様式で骨盤と上部体幹角度は, 前額面と水平 面ともに逆方向に動く傾向が見られたが，駆動中の角 度の変化量には大きな変化はなかった。車いす下肢駆 動は, 駆動側の足部にて床を下後方向に押し付けて行 う動作である。先行研究 3,4$)$ と本研究から上部体幹の前 後屈角度の位置が変化しても駆動中の骨盤傾斜や回旋 角度, 上部体幹側屈や回旋角度は変化せず, 骨盤と上 部体幹が逆の方向に動く傾向があったことから, 駆動 側下肢の運動中に非駆動側の股関節屈筋群や膝伸筋群, 体幹筋群が骨盤や下部体幹を固定するために働いてい 


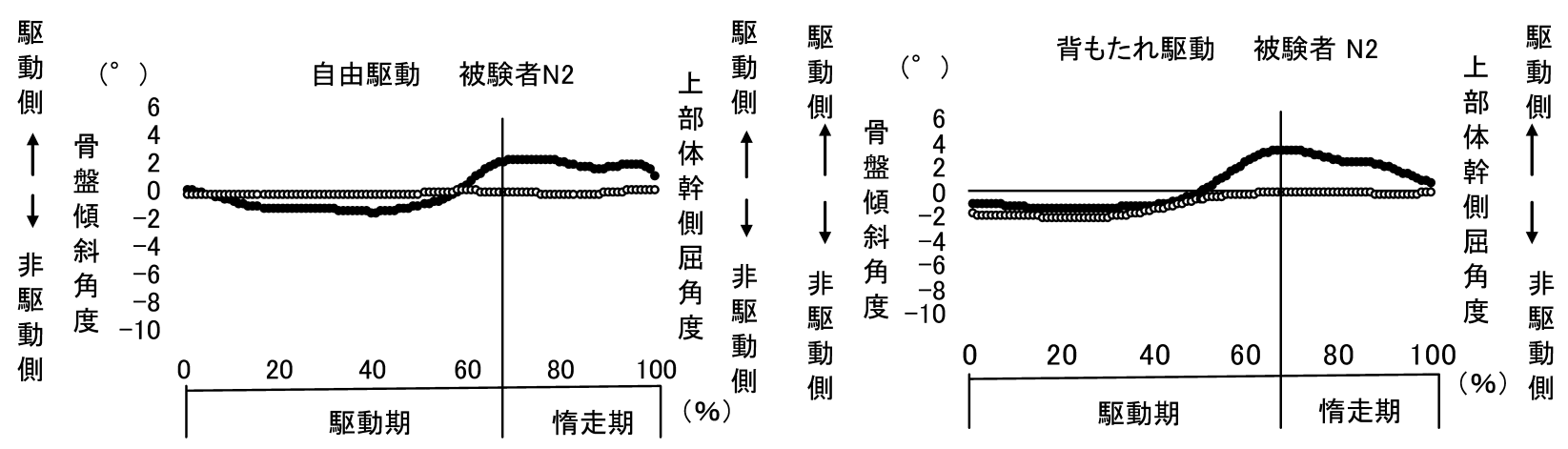

○骨盤角度 O上部体幹角度

図2 駆動様式別の骨盤傾斜，上部体幹側屈角度例
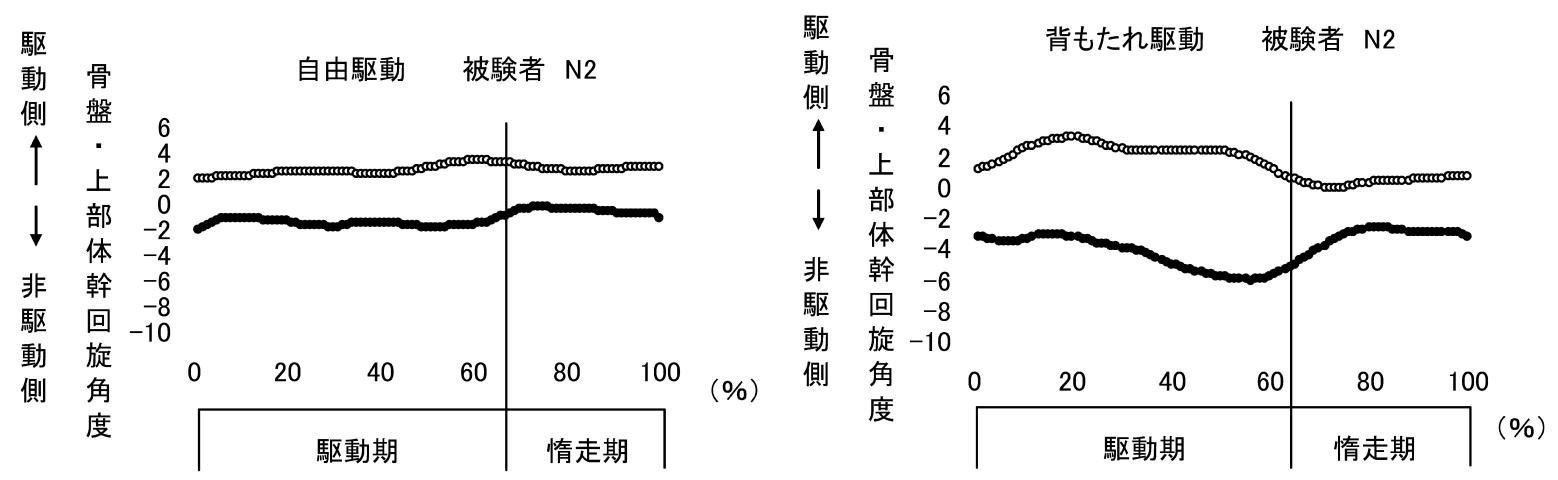

○骨盤角度 O上部体幹角度

図3 駆動様式別の骨盤回旋, 上部体幹回旋角度例

表2 駆動様式別の骨盤と上部体幹角度の変化量

単位: ${ }^{\circ}$

\begin{tabular}{lcccc}
\hline & 骨盤回旋角度 & 上部体幹回旋角度 & 骨盤傾斜角度 & 上部体幹側屈角度 \\
\hline 自由駆動 & $2.78 \pm 0.97$ & $1.78 \pm 0.58$ & $2.07 \pm 0.36$ & $0.54 \pm 0.23$ \\
背もたれ駆動 & $2.19 \pm 1.01$ & $1.68 \pm 1.37$ & $1.37 \pm 0.63$ & $1.57 \pm 0.63$ \\
\hline
\end{tabular}

駆動様式別の值は被験者 3 名の平均值と標準偏差を示す.

ると考えられる。

背もたれ駆動において駆動速度の増加に比べてスト ライドの増加は少なく, ケイデンスが増加する傾向が あり, 静止座位から屈曲ピーク時までの骨盤後傾のズ レ角度が大きくなる傾向を示した。車いすを前進させ る重要な筋はハムストリングスであるが6), この筋は 骨盤を後傾させる作用をもつ。本研究の結果では, 背 もたれ駆動において, 駆動開始から駆動期の股関節屈
表3 静止座位から屈曲ピーク時までの 骨盤後傾のズレ角度

\begin{tabular}{ll} 
& \multicolumn{1}{c}{ 単位 : ${ }^{\circ}$} \\
\hline 骨盤ズレ角度 \\
\hline 自由駆動 & $-1.27 \pm 0.35$ \\
背もたれ駆動 & $-4.77 \pm 1.65$ \\
\hline
\end{tabular}

駆動様式別の值は被験者 3 名の平均值と 標準偏差を示す. 
曲運動時に骨盤後傾のズレ角度が大きくなる事から, ハムストリングスが骨盤を後傾するように作用したこ とが考えられる。骨盤後傾が大きいほどハムストリン グスの起始部と停止部は近づき, 筋張力は小さくなり, 働きにくくなることが予測されることから，ストライ ドをできるだけ大きくし, ケイデンスを増加させて駆 動していることが推察される。

本研究の対象とした3名の健常者駆動の結果から, 2 条件の駆動様式ともに骨盤と上部体幹角度が前額面と 水平面上で変化しない傾向があることが示された。片 麻痺者では, 骨盤と上部体幹が麻痺側に偏移する傾向 がある7)との報告があることから, 健常者では体幹伸 展位での車い寸片側下肢駆動でも姿勢を左右対称に保 つだけの能力があることが考えられる。

今回, 健常者で得られた結果から片麻痺者を対象に 同様の計測を行いたい。また，体幹と骨盤の動きだけ ではなく, 筋電図を使用して体幹や駆動側下肢のデー タも合わせて計測していきたい。

謝辞 本研究に際し, ご指導頂きました国際医療福祉 大学大学院福祉援助工学分野の野村歓教授, 計測設備 と被験者確保にご協力いただいた農協共済中伊豆リ八
ビリテーションセンタースタッフー同，計測時にご協 力頂いた広瀬整形外科リウマチ科の岩橋洋子先生に深 謝致します。

\section{引用文献}

1) 植松光俊, 山田美佳, 江口英範 : 片麻痺患者の車い寸駆動に 影響する因子一シート高・奥行きについて一. 理学療法学, 1994, 21: 256-263.

2) 岩本あきこ, 東 祐二, 津曲優子・他 : フットレストの高さ が車い寸駆動におよぼす影響について。作業療法, 2004, 23: 198.

3) 張替 徹, 木村伸也, 加倉井周一: 車い寸片手片脚駆動の動 作分析（第1 報）一健常人について一. リ八医学, 1995, 32: 225-231.

4) 田中正則, 金子秀雄, 加倉井周一・他 : 片麻痺者の車い寸片 手片脚駆動の動作分析. 理学療法学, 1995, 22: 229.

5) Cooper RA : 車いすのヒューマンデザイン. 田中 理, 大鍋 寿一 (訳), 医学書院, 東京, 2000, pp17-31.

6) Engstrom B : エルゴノミック・シーティング. 桂 律也, 山 野 香（訳）, ラックヘルスケア株式会社, 大阪, 2003, pp216225.

7) 川田教平, 山本澄子 : 片麻痺者の車い寸片側下肢駆動の分 析. 理学療法科学, 2008, 23: 789-793. 